Ju.S. Mazurenko

\title{
Tailoring of Magnesium Substitution on Structure and Magnetic Properties of Lithium Ferrites
}

\author{
Ivano-Frankivsk National Medical University, Ivano-Frankivsk, Ukraine, yumazurenko@ifnmu.edu.ua
}

\begin{abstract}
In this study is reported influence of $\mathrm{Mg}^{2+}$ doping on structure and magnetic properties of nano-sized $\mathrm{Li}_{0.5} \mathrm{Fe}_{2.5}$ $\mathrm{xMgxO}_{4}(0.0,0.2,0.4,0.6,0.8)$ synthesized using sol-gel auto-combustion method. The $\mathrm{X}$-ray diffractometric and Mössbauer data analysis of samples confirmed the formation of pure $\mathrm{Li}_{0.5} \mathrm{Fe}_{2.5-\mathrm{x}} \mathrm{MgXO}_{4}$ nanoparticles ranges crystallite size from $15 \mathrm{~nm}$ to $35 \mathrm{~nm}$. Iron ions are redistributed on the A and B sites in a ratio of approximately 4:6, and magnesium ions 8:2, respectively. The advantages of the B position of the above ions are as follows: $\mathrm{Li}^{+}>\mathrm{Fe}^{3+}>\mathrm{Mg}^{2+}$. RT-Mössbauer indicated the presence of ${ }^{57} \mathrm{Fe}$ in both sublattices. Position identification was performed based on the distribution of the over exchange fields and isomeric shift data. Magnetic characteristics were obtained for rings made of synthesized material. They showed a non-monotonic dependence on the composition and found significantly higher rates compared to similar materials obtained by solid-phase synthesis.
\end{abstract}

Keywords: ferrites, sol-gel autocombustion, structural research, magnetic properties, spinels, soft magnets.

Received 14 February 2021; Accepted 5 April 2021.

\section{Introduction}

Technologically, ferrites are very important materials due to their interesting magnetic and electrical properties, which can be used for use in high-capacity batteries, electrochromic displays, for water purification, lowmagnetic liquids, intercalated electrodes in rechargeable batteries and as a strong oxidant and much more [1-8]. The cubic lithium ferrite spinel $\mathrm{LiFe}_{5} \mathrm{O}_{8}$ [9] is one of the most important ferrites. It belongs to the group of magnetic materials with high Curie temperature about $893 \mathrm{~K}$ [9], square hysteresis loop and high magnetization.

When using ferrites in the high and ultrahigh frequencies, it is desirable to minimize the conductivity of the material. Therefore, the substitution of $\mathrm{Fe}^{3+}$ for $\mathrm{Mg}^{2+}$ to ensure electro-neutrality will reduce the content of $\mathrm{Fe}^{2+}$, which plays a major role in the jumping conductivity of ferrite. Ionic radii $\mathrm{Mg}^{2+}$ and $\mathrm{Fe}^{3+}$ very close (approximately $0.064 \mathrm{~nm}$ each), so, according to Vegard's law, the substitution should not significantly distort the lattice [8]. Magnesium ions are able to be in both the octahedral and tetrahedral sublattices, which will allow substitution in both sublattices. Since magnesium is divalent, the substitution of magnesium in the formed ferrite reduces the probability of $\mathrm{Fe}^{2+}$ formation, reduces the conductivity and improves the magnetic properties.

However, magnesium is non-magnetic, so it does not significantly affect the magnetic characteristics itself. In addition, substituting in both sublattices A and B, in the General case, does not contribute to the magnetic properties of the synthesized systems. Therefore, it is important to investigate the effect of Magnesium substitution on the structure, electrical and magnetic properties of materials.

The existing chemical methods used for lithium ferrite synthesis, such as co-precipitation, crystallization by glazing, hydrothermal, mechano-chemical and sol-gel method requires high temperature above $1400 \mathrm{~K}$. Such a high temperature can cause loss of lithium, which is released at temperatures above $1273 \mathrm{~K}$, also high sintering process reduces the specific surface area [9, 10], deteriorating its electrical and magnetic properties of ferrites. Thus, reparation of lithium ferrite at low temperatures is of considerable interest. To improve the properties of the material, nanosized lithium ferrite was synthesized by sintering free sol-gel auto-combustion. In 
order to study the effect of substitution on the structure, electrical and magnetic properties in the synthesis of ferrite, iron ions were replaced by magnesium ions according to the formula $\mathrm{Li}_{0.5} \mathrm{Fe}_{2.5-\mathrm{x}} \mathrm{Mg}_{\mathrm{x}} \mathrm{O}_{4}$, with $\mathrm{x}=0.0$ to 0.8 .

\section{Experimental}

Magnesium-substituted lithium ferrites were synthesized with aqueous solutions of metal nitrates and citric acid (analytical grade). Metal nitrates and citric acid were mixed dropwise on a magnetic stirrer in a molar ratio of metals to citric acid 1:1. The metal nitrate solution with citric acid slowly evaporated in the oven to form a viscous gel. Subsequent drying was performed to completely remove the adsorbed water at $383 \mathrm{~K}$. The resulting xerogel was placed in an oven with temperature of about $473-493 \mathrm{~K}$, after which the mixture ignited and the reaction formed a product, which was investigated using an X-ray diffractometer DRON-3 in $\mathrm{CuK} \alpha$ - radiation.

For the analysis of experimental diffraction patterns, the full-profile analysis by Rietveld's refinement method with use of programs FullProf and PowderCell was applied. The Mössbauer absorption spectra of ${ }^{57} \mathrm{Fe}$ at $293 \mathrm{~K}$ were obtained in the mode of constant accelerations on the Mössbauer spectrometer MS1104EM using a source of $\gamma$-quanta ${ }^{57} \mathrm{Co}$ in the chrome matrix. Mathematical processing of the obtained spectra was performed using a universal computer program Univem [10].

For magnetic studies of the synthesized powder, rings with outer and inner diameters of 18 and $10 \mathrm{~mm}$, respectively, and a thickness of $3 \mathrm{~mm}$ were formed. The primary and secondary windings were wound on the rings in the amount of 20 and 600 turns of copper insulated wire, respectively.

The magnetic properties of the synthesized magnesium-substituted lithium ferrite samples as a function of composition at $293 \mathrm{~K}$ and a frequency of $50 \mathrm{~Hz}$ were obtained on a ferrometer F-64 at a maximum value of the applied field of $600 e$. Based on magnetic measurements from the hysteresis loop, the following magnetic parameters were obtained.

Experimental magnetic moment per formula unit $\mathrm{m}_{\text {exp }}$, expressed in Bohr magnetons $\left(\mu_{\mathrm{B}}\right)$ can be calculated by the following formula [10]:

$$
m_{\exp }=\frac{M_{W}{ }^{M} S}{5585}
$$

where $\mathrm{M}_{\mathrm{W}}$ - molecular weight of the sample and $\mathrm{M}_{\mathrm{S}}$ saturation magnetization in $e m u / g$.

The magnetic anisotropy constant $(\mathrm{K})$ can be expressed by the saturation magnetization $\left(\mathrm{M}_{\mathrm{S}}\right)$ and magnetic coercive force $\left(\mathrm{H}_{\mathrm{C}}\right)[10]$ as:

$$
K=\frac{{ }_{S} H_{c}}{0.96}
$$

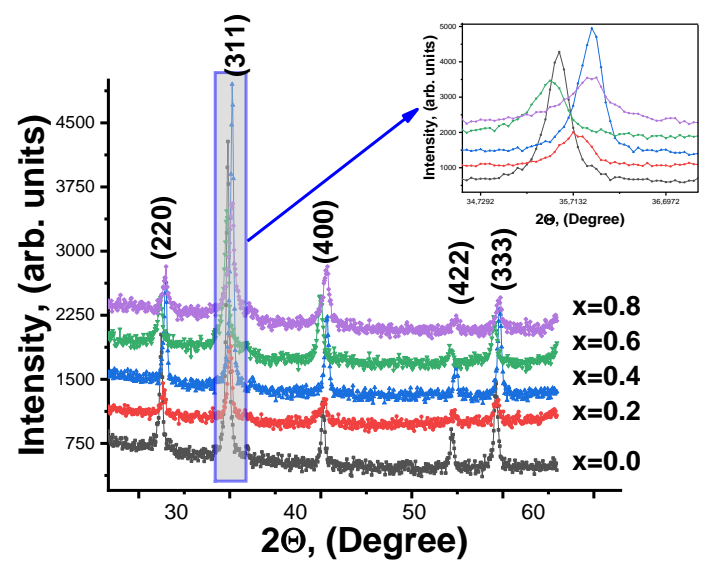

Fig. 1. X-ray diffraction spectra of $\mathrm{Li}_{0.5} \mathrm{Fe}_{2.5-\mathrm{x}} \mathrm{Mg}_{\mathrm{x}} \mathrm{O}_{4}$ $(\mathrm{x}=0 ; 0.2 ; 0.4 ; 0.6 ; 0.8)$.

\section{Results and discussion}

\subsection{Structural analysis and morphology}

Figure 1 shows X-ray diffraction patterns of the synthesized samples of each composition. As can be seen from the figure 1 , all the obtained compounds are singlephase spinels, and the system of $\mathrm{Li}_{0.5} \mathrm{Fe}_{2.5} \mathrm{O}_{4}(\mathrm{x}=0.0)$ composition belongs to the spatial group $\mathrm{P} 432$ [JCPDS No 76-1591], the so-called superordered spinel structure, as evidenced by the presence of superstructural peaks (110), (210) and (211). This superstructure occurs due to the ordered arrangement of lithium and iron ions in a ratio of $1: 3$ in the [100] crystallographic direction. All other compounds of the composition $\mathrm{Li}_{0.5} \mathrm{Fe}_{2.5-\mathrm{x}} \mathrm{Mg}_{\mathrm{x}} \mathrm{O}_{4}$ $(\mathrm{x}=0.0 ; 0.2 ; 0.4 ; 0.6 ; 0.8)$ found belonging to a spatial group $\mathrm{Fd} 3 \mathrm{~m}$, because the presence of magnesium ions in the octahedral lattice disturbs the order in the arrangement of iron and lithium ions.

Peak displacement, in particular (311), (Fig. 1, magnification), is a consequence of the change of the lattice constant. Ionic radii $\mathrm{Mg}^{2+}$ and $\mathrm{Fe}^{3+}$ very close (approximately $0.064 \mathrm{~nm}$ each), to ensure the electroneutrality of the system as a whole, charged vacancies are formed in the ferrite, which leads to an increase in the lattice constant.

Figure 2 shows the distribution of cations on the

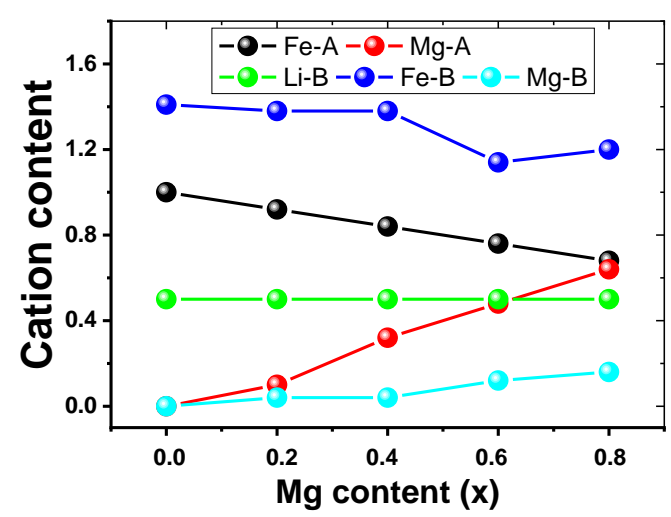

Fig. 2. Distribution of cations on sublattices in $\mathrm{Li}_{0.5} \mathrm{Fe}_{2.5-\mathrm{x}} \mathrm{Mg}_{\mathrm{x}} \mathrm{O}_{4}$. 
lattice of spinel depending on the content of magnesium ions. $\mathrm{Li}^{+}$cations occupy only B-positions, while $\mathrm{Fe}^{3+}$ and $\mathrm{Mg}^{2+}$ ions occupy both $\mathrm{A}-$ and $\mathrm{B}$-sites. Iron ions are redistributed on the $A$ and $B$ sites in a ratio of approximately 4:6 and magnesium ions 8:2, respectively. According to the results of X-ray diffraction analyses, the advantages of the $\mathrm{B}$ position of the above ions are as follows: $\mathrm{Li}^{+}>\mathrm{Fe}^{3+}>\mathrm{Mg}^{2+}$.

The data in Table 1 indicate that all the synthesized samples are nanoscale and larger values of the experimental constant lattice compared to the theoretical caused by the influence of the surface due to the small size of the crystallites. Slightly higher values of CSR in the Selyakov-Scherrer method are because only one peak of intensity (the third) was taken into account, and the

Table 1

The size of the coherent scattering regions (CSR) of $\mathrm{Li}_{0.5} \mathrm{Fe}_{2.5-\mathrm{x}} \mathrm{Mg}_{\mathrm{x}} \mathrm{O}_{4}$ ( $\left.\mathrm{x}=0.2 ; 0.4 ; 0.6 ; 0.8\right)$, determined by the methods of Selyakov-Scherrer and Williamson Hall

\begin{tabular}{|c|c|c|}
\hline $\begin{array}{c}\mathrm{Mg} \\
\text { Content } \\
(\mathrm{x})\end{array}$ & $\begin{array}{c}\text { CSR, nm }( \pm 0.1) \\
\text { Selyakov- } \\
\text { Scherrer Method }\end{array}$ & $\begin{array}{c}\text { CSR, nm }( \pm 0.1) \\
\text { Williamson Hall } \\
\text { Method }\end{array}$ \\
\hline 0.0 & 42 & 40.0 \\
\hline 0.2 & 17 & 16.8 \\
\hline 0.4 & 24 & 23.6 \\
\hline 0.6 & 16 & 15.4 \\
\hline 0.8 & 15 & 14.4 \\
\hline
\end{tabular}

Williamson-Hall method takes into account all reflexes.

The height of the peaks is more influenced by the size of the crystallites (the greater the coherent scattering region, the narrower and higher the peaks) than the content of the substitution. Obtained systems were not additionally annealed, so the size of the CSR is on average $14-24 \mathrm{~nm}$. On contrary, the sample $\mathrm{x}=0.0$ was subjected to additional annealing, which led to the aggregation of crystallites.

It is known, that with increasing the angle of reflection, the half-width of the peak increases, so taking into account all the reflexes can give an average value, which may be slightly less than for one randomly selected reflex. Also, in determining the $\beta_{1 / 2}$ value took into account the instrumental broadening caused by the discrepancy of the X-ray beam and the width of the limiting slits, which was determined using a reference sample. This sample was a well-annealed sample of lithium-iron spinel obtained by ceramic method. The $\mathrm{X}$-ray density for each composition was determined based on the ratio [11]:

$$
d_{x}=\frac{Z M}{N a^{3}},
$$

where $\mathrm{Z}$ - the number of molecules per unit cell (for a spinel lattice $Z=8), M$ - the mass of the molecule of the ferrite sample, $\mathrm{N}$ - Avogadro's number and $a$ - lattice constant. It is found that, X-ray density decreases with increasing $\mathrm{x}$. This can be explained by the fact that the atomic weight of $\mathrm{Mg}^{2+}$ (24.31) is less than that of $\mathrm{Fe}^{3+}$ (55.8). Accordingly, the values of natural density $\rho$, relative porosity $\mathrm{P}, \%$, and active surface area $\mathrm{S}$ were calculated for the systems of each composition, which are shown in Table 2.

The table shows that the average crystal size of the synthesized samples is in the region of $14-21 \mathrm{~nm}$ and the surface area is $116-268 \mathrm{~m}^{2} / \mathrm{g}$, which indicates the nanocrystalline nature of the obtained samples. The specific surface area of the synthesized ferrites is the set of visible surface areas of ferrite particles per unit mass. The size of the crystallites and the specific surface area are inversely proportional to each other, as can be seen from the Table 2. The smaller size of the crystallites gives a larger surface area, which affects the properties of ferrites.

The SEM images of all samples are shown in Figure 3. The average particle size of ferrites of all compositions obtained from SEM images is in the region of $78-87 \mathrm{~nm}$. It can be seen that the average grain size of ferrites of different composition obtained by the SEM method is larger than the particle sizes obtained by the XRD method (Table 2). This can be explained by the fact that each grain is the result of agglomeration of several nanocrystals. Micro images show an agglomerated granular structure with clusters of fine particles connected to each other. The morphology of the surface is completely homogeneous and regular and consists of cubic, close to spherical particles. This morphology of the samples demonstrates

Table 2

Microstructural parameters of systems

\begin{tabular}{|c|c|c|c|c|c|}
\hline \multicolumn{6}{|c|}{$\mathrm{Li}_{0.5} \mathrm{Fe}_{2.5-\mathrm{x}} \mathrm{Mg}_{\mathrm{x}} \mathrm{O}_{4}$} \\
\hline $\begin{array}{l}\overparen{\Xi} \\
\stackrel{ \pm}{0} \\
\stackrel{ \pm}{0} \\
0 \\
0 \\
\sum^{\infty}\end{array}$ & 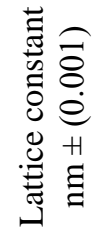 & 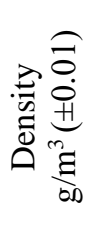 & 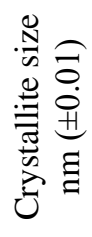 & 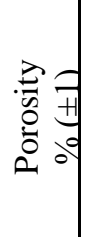 & 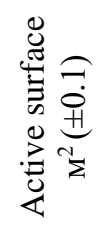 \\
\hline 0.2 & 0.833 & 2.13 & 16.79 & $\begin{array}{c}0.5 \\
4\end{array}$ & 167.7 \\
\hline 0.4 & 0.833 & 2.42 & 21.33 & $\begin{array}{c}0.4 \\
6\end{array}$ & 116.4 \\
\hline 0.6 & 0.835 & 1.99 & 15.04 & $\begin{array}{c}0.5 \\
4\end{array}$ & 200.4 \\
\hline 0.8 & 0.836 & 1.56 & 14.35 & $\begin{array}{c}0.6 \\
3\end{array}$ & 268.3 \\
\hline
\end{tabular}
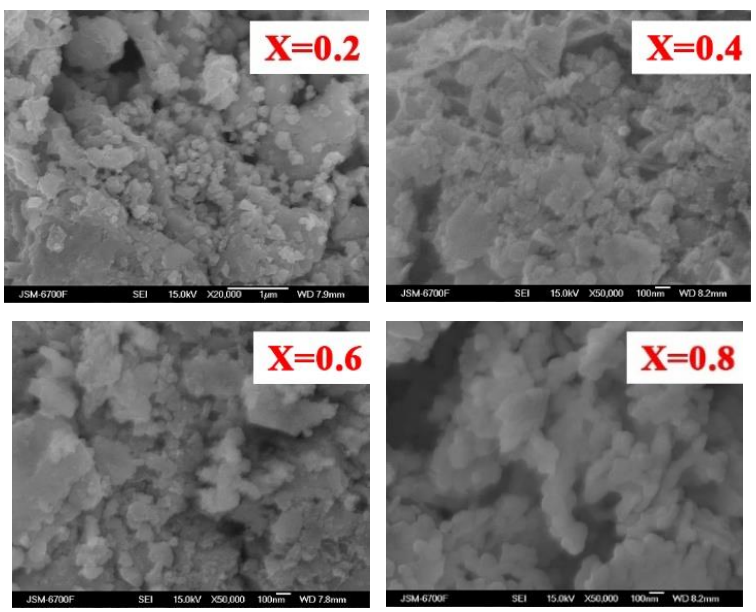
the fine-grained nature of the particles. Microphotographs confirm the nanoscale nature of the synthesized systems and are also evidence of particle agglomeration.

\subsection{Mossbauer studies}

Mossbauer spectra of ${ }^{57} \mathrm{Fe}$ at $293 \mathrm{~K}$ of $\mathrm{Li}_{0.5} \mathrm{Fe}_{2.5-\mathrm{x}} \mathrm{Mg}_{\mathrm{X}} \mathrm{O}_{4}(\mathrm{x}=0.2 ; 0.4 ; 0.6 ; 0.8)$, obtained at $\mathrm{pH}$ values of the reaction medium equal 7 are shown at Figure 4. All the obtained spectra are a superposition of three magnetically ordered components and two (for a system with $\mathrm{x}=0.4$ one) paramagnetic doublets. Magnetic fields with relatively large values are responsible for the octahedral and tetrahedral environment of nuclei ${ }^{57} \mathrm{Fe}$. These values change with increasing concentration of the substituent element. Figure 5 shows the dependences of the magnitude of the ${ }^{57} \mathrm{Fe}$ magnetic fields in the octa $\mathrm{H}_{\mathrm{B}}$ and tetra $\mathrm{H}_{\mathrm{A}}$ environment. The increase in the value of the effective magnetic fields in the case of $x=0.2$ can obviously be explained by the peculiarities of the structure.

The nonmagnetic environment, obviously, can explain the increase in the paramagnetic doublet with increasing concentration of magnesium ions. With increasing substitution, the number of nonmagnetic iron neighbors increases, and when increasing to three, this iron nucleus is removed from the on-domain interaction.

The presence of the third magnetically ordered component on the Mössbauer spectra with values of

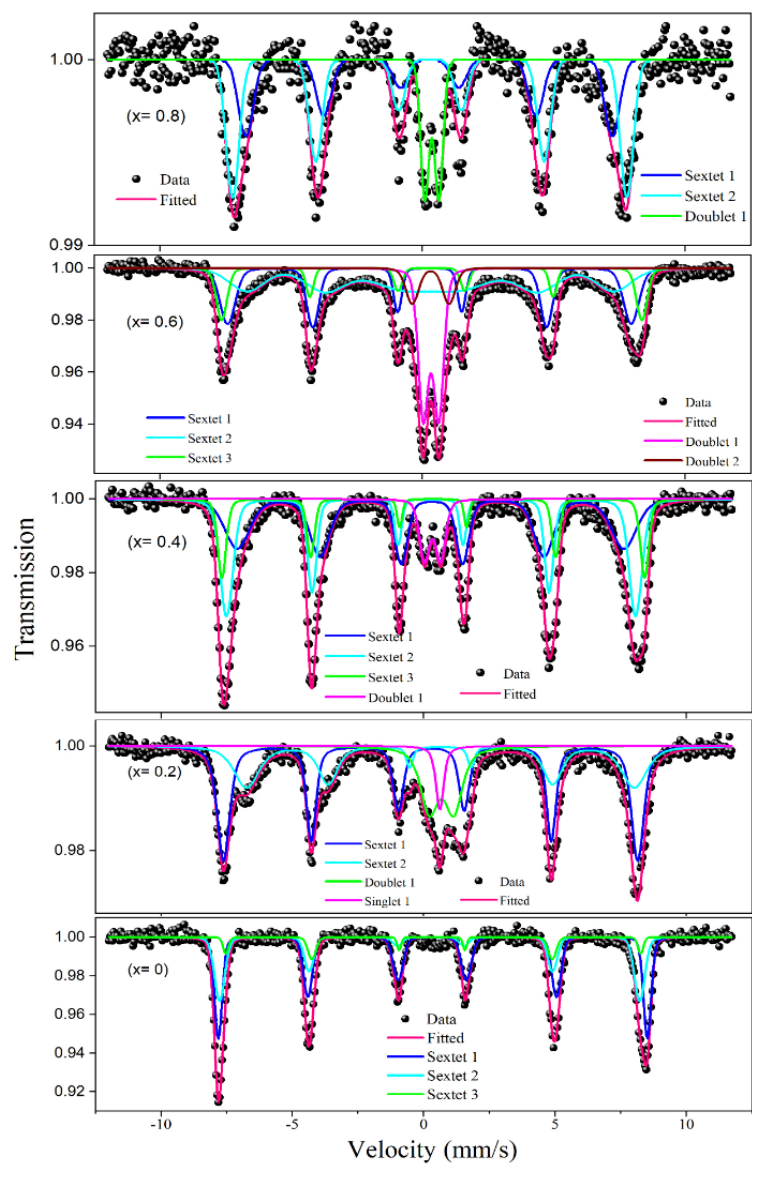

Fig. 4. RT-Mössbauer spectra of ${ }^{57} \mathrm{Fe}$ a of $\mathrm{Li}_{0.5} \mathrm{Fe}_{2.5-\mathrm{X}} \mathrm{Mg}_{\mathrm{X}} \mathrm{O}_{4}$ with $7 \mathrm{pH}$.

effective magnetic fields several tens of kOe smaller, we

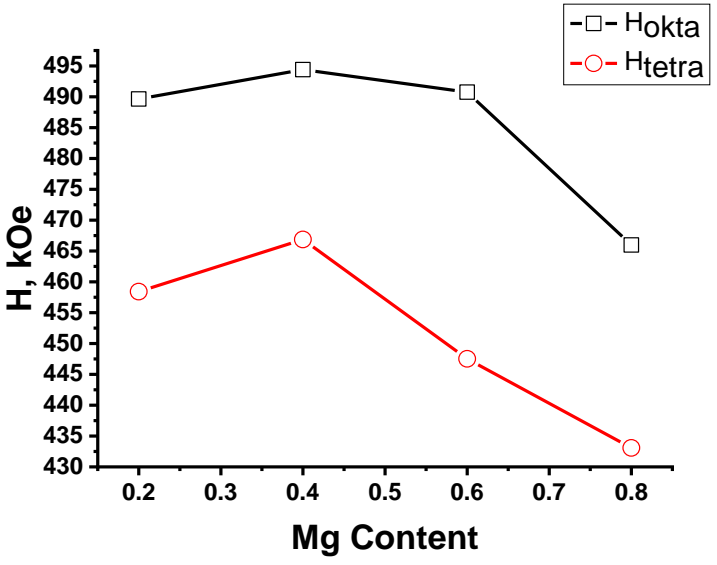

Fig. 5. Dependence of magnetic fields $\mathrm{H}_{\mathrm{A}}$ and $\mathrm{H}_{\mathrm{B}}$ on the $\mathrm{Mg}$ content in $\mathrm{Li}_{0.5} \mathrm{Fe}_{2.5-\mathrm{X}} \mathrm{Mg}_{\mathrm{X}} \mathrm{O}_{4}$.

attributed to the ${ }^{57} \mathrm{Fe}$ nuclei in the upper layer. Reduction of effective magnetic fields on ${ }^{57} \mathrm{Fe}$ nuclei associated with different numbers of indirect exchange bonds for internal and surface iron ions, which are deprived of a significant part of such bonds [12-15].

It is possible to estimate the particle size, taking into account the value of the areas under the sub spectra. The assumption of a spherical particle shape was taken into account. The results of iron distribution calculation by Aand B-sites generally coincide. Slightly higher values of iron content in the A-site for systems $\mathrm{Li}_{0.5} \mathrm{Fe}_{2.1} \mathrm{Mg}_{0.4} \mathrm{O}_{4}$ and $\mathrm{Li}_{0.5} \mathrm{Fe}_{1.9} \mathrm{Mg}_{0.6} \mathrm{O}_{4}$ according to $\mathrm{X}$-ray structural data analysis, apparently, are explained by the fact that at high values of substitution by nonmagnetic ions some iron atoms are found to be surrounded by nonmagnetic neighbors in the amount of more than three and are excluded from indirect magnetic interaction. This is confirmed by the results of Mössbauer spectroscopy. According to it, a paramagnetic doublet is observed on the Mössbauer spectra.

\subsection{Magnetic measurements}

Magnetic measurements at $293 \mathrm{~K}$ were performed using a ferrometer F-64. For magnetic measurements, ferrite samples were made in the form of rings with inner and outer diameters of 20 and $10 \mathrm{~mm}$, respectively, and a height of three $\mathrm{mm}$. They were additionally annealed at $723 \mathrm{~K}$ for $4 h$ at a heating rate of $4^{0} \mathrm{C} / \mathrm{min}$. The primary coil was wound on the rings of 20 turns and the secondary - of 600. The hysteresis loops for all compositions of $\mathrm{Li}-\mathrm{Mg}$ ferrites are shown in Fig. 6 show the dependence of the magnetization value (M) on the applied magnetic field (H).

The following magnetic parameters were obtained from the hysteresis loop: saturation magnetization $\mathrm{M}_{\mathrm{S}}$ (maximum value of magnetization), remnant magnetization - $M_{R}$ (magnetization at zero field), coercivity $-\mathrm{H}_{\mathrm{C}}$ (the value of the magnetic field required to reduce the magnetization of the material to zero after magnetization of the sample to saturation).

These magnetic parameters were used to illustrate the magnetic properties of the synthesized ferrite materials. Measured magnetic parameters $\left(\mathrm{M}_{\mathrm{S}}, \mathrm{M}_{\mathrm{R}}\right.$ and $\left.\mathrm{H}_{\mathrm{C}}\right)$ for all synthesized samples in the applied magnetic field $(\mathrm{H})$ are shown in Table 3. 


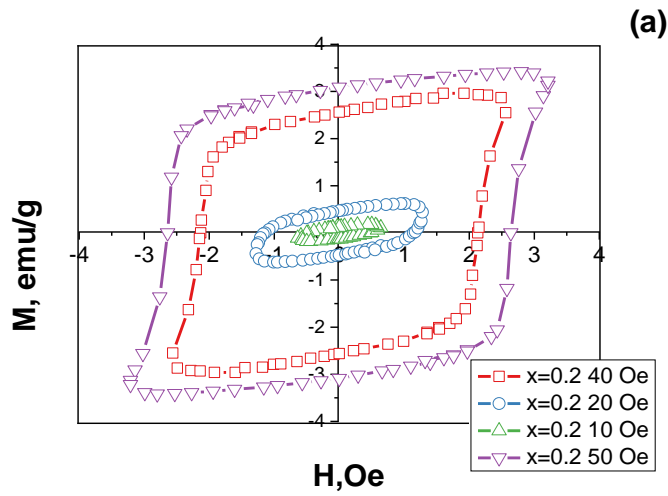

(c)

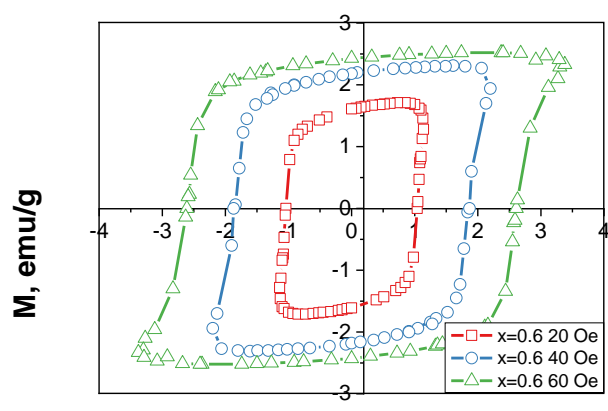

$\mathrm{H}, \mathrm{Oe}$

(a)

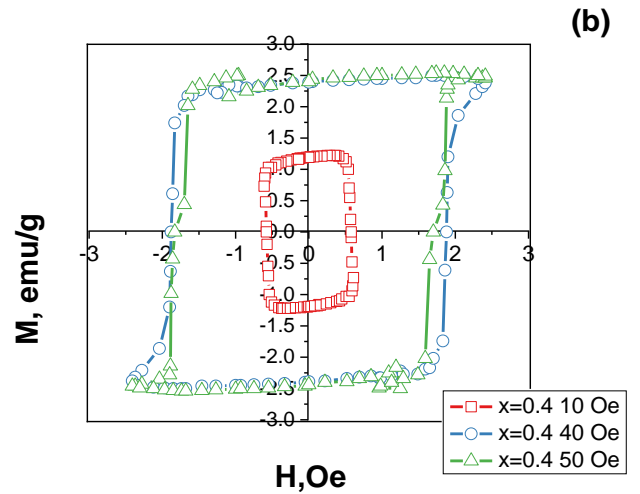

(d)

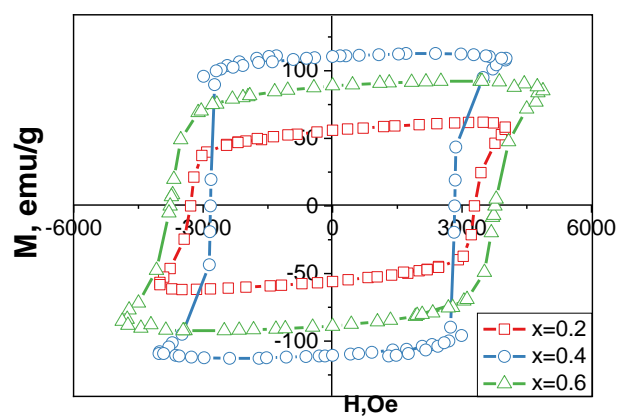

Fig. 6. Hysteresis loops of system $\mathrm{Li}_{0.5} \mathrm{Fe}_{2.5-\mathrm{X}} \mathrm{Mg}_{\mathrm{X}} \mathrm{O}_{4}$. $\mathrm{Li}_{0,5} \mathrm{Fe}_{2,3} \mathrm{Mg}_{0,2} \mathrm{O}_{4}$ (a), $\mathrm{Li}_{0.5} \mathrm{Fe}_{2.1} \mathrm{Mg}_{0.4} \mathrm{O}_{4}$ (b), $\mathrm{Li}_{0.5} \mathrm{Fe}_{1.9} \mathrm{Mg}_{0.6} \mathrm{O}_{4}$ (c), and (d) loops for all compositions at an external field $60 \mathrm{Oe}$.

Table 3

Magnetic parameters of $\mathrm{Li}_{0,5} \mathrm{Fe}_{2,3} \mathrm{Mg}_{0,2} \mathrm{O}_{4}, \mathrm{Li}_{0.5} \mathrm{Fe}_{2.1} \mathrm{Mg}_{0.4} \mathrm{O}_{4}, \mathrm{Li}_{0.5} \mathrm{Fe}_{1.9} \mathrm{Mg}_{0.6} \mathrm{O}_{4}$ systems

\begin{tabular}{|c|c|c|c|c|c|c|c|}
\hline $\begin{array}{c}\text { Magnesium } \\
\text { concentration } \\
\mathrm{x}\end{array}$ & $\begin{array}{c}\text { Molar } \\
\text { mass } \\
\mu\end{array}$ & $\begin{array}{c}\text { Coercivity } \\
\mathrm{Hc}\end{array}$ & $\begin{array}{c}\text { Remnant } \\
\text { Magnetization } \\
\mathrm{M}_{\mathrm{R}}\end{array}$ & $\begin{array}{c}\text { Saturation } \\
\text { Magnetization } \\
\mathrm{Ms}\end{array}$ & $\begin{array}{c}\text { Anisotropic } \\
\text { Constant } \\
\mathrm{K} \times 10^{3}\end{array}$ & $\begin{array}{c}\text { Magnetic } \\
\text { moment } \\
\mathrm{m}_{\mathrm{ef}}\end{array}$ & $\mathrm{M}_{\mathrm{R}} / \mathrm{Ms}$ \\
\hline 0.2 & 200.78 & 3289.7 & 33,35 & 36,8 & 126 & 1,32 & 0.91 \\
\hline 0.4 & 194.46 & 2829.3 & 135,37 & 138,07 & 651 & 4,81 & 0.98 \\
\hline 0.6 & 188.16 & 3763.9 & 97,95 & 101,57 & 398 & 3,43 & 0.96 \\
\hline $\begin{array}{c}\text { measurement } \\
\text { errors }\end{array}$ & $\pm 0,01$ & $\pm 0,1$ & $\pm 0,01$ & $\pm 0,01$ & 1 & $\pm 0,01$ & $\pm 0,01$ \\
\hline
\end{tabular}

The highest magnetic properties were found in the sample with a degree of substitution of 0.4 . Although in our case, the magnetic ions of iron are replaced by nonmagnetic ions of magnesium, then the magnetic properties should decrease with substitution.

However, the results of the experiment showed otherwise: there is a non-monotonic dependence of the magnetic characteristics on the composition. Obviously, this phenomenon can be explained by the fact that in ferrites the resulting magnetic moment is defined as the result of A-B sublattice interaction.

The magnetic moments of the tetrahedral and octahedral sublattices are generally oriented antiparallel. Therefore, the resulting magnetic moment will be defined as the difference between the magnetic moments of the Aand the B-sites. Upon substitution, as shown by the cationic distribution, magnesium ions are redistributed in the sublattice as 8:2 (8 - in the tetrahedral sublattice), so that the resulting balance of magnetic ions was in favor of the octahedral sublattice. The decrease in the magnetic parameters in the sample $\mathrm{x}=0.6$ is compared with $\mathrm{x}=0.4$, obviously associated with a general decrease in the number of magnetic ions.

Based on magnetic measurements, namely the value of the magnetic moment per formula unit $\mathrm{m}_{\mathrm{ef}}$, we can calculate the iron content in the tetrahedral (A) and octahedral (B) sublattices involved in magnetization. Comparisons of the distribution of iron on the lattice according to the results of X-ray diffraction analysis and magnetic measurements are shown in Table 4.

The results of iron distribution calculation by $\mathrm{A}$ and B-sites generally coincide. Slightly higher values of iron content in the A-site for systems $\mathrm{Li}_{0.5} \mathrm{Fe}_{2.1} \mathrm{Mg}_{0.4} \mathrm{O}_{4}$ and $\mathrm{Li}_{0.5} \mathrm{Fe}_{1.9} \mathrm{Mg}_{0.6} \mathrm{O}_{4}$ according to $\mathrm{X}$-ray structural data analysis, apparently, are explained by the fact that at high values of substitution by nonmagnetic ions some iron atoms are found to be surrounded by nonmagnetic neighbors in the amount of more than three and are excluded from indirect magnetic interaction. This is confirmed by the results of Mössbauer spectroscopy. 
Distribution of $\mathrm{Fe}^{3+}$ ions by lattices in the structure of synthesized systems

\begin{tabular}{|c|c|c|c|c|}
\hline \multirow{2}{*}{$\begin{array}{c}\text { Magnesium } \\
\text { concentration } \\
\mathrm{x}\end{array}$} & \multicolumn{2}{|c|}{ X-ray data analysis } & \multicolumn{2}{c|}{ Magnetic measurements } \\
\cline { 2 - 5 } & A-site & B-site & 1,0 & B-site \\
\hline 0.2 & 0,92 & 1,38 & 0,57 & 1,28 \\
\hline 0.4 & 0,84 & 1,26 & 0,61 & 1,53 \\
\hline 0.6 & 0,76 & 1,14 & $\pm 0,01$ & $\pm 0,01$ \\
\hline $\begin{array}{c}\text { measurement } \\
\text { errors }\end{array}$ & $\pm 0,01$ & $\pm 0,01$ & \\
\hline
\end{tabular}

According to it, a paramagnetic doublet is observed on the Mössbauer spectra. Thus, the coincidence of the results performed by independent methods indicates the reliability of the obtained results.

\section{Conclusions}

The sol-gel auto-combustion method for the synthesis of single-phase magnesium-substituted lithium ferrite of the Fd3m space group with crystal lithium sizes of 15 - 30 $\mathrm{nm}$ was tested. It is shown that the $\mathrm{pH}$ of the active medium during synthesis plays a crucial role in the formation of the morphology of the obtained systems. Based on the results of X-ray analysis, it is shown that $\mathrm{Li}^{+}$ cations occupy only the B-position, while $\mathrm{Fe}^{3+}$ and $\mathrm{Mg}^{2+}$ ions occupy both the A- and B-sites. Iron ions are redistributed on the $\mathrm{A}$ - and $\mathrm{B}$-sites in a ratio of approximately 4:6, and magnesium ions 8:2, respectively. The advantages of the $\mathrm{B}$ position of the above ions are as follows: $\mathrm{Li}^{+}>\mathrm{Fe}^{3+}>\mathrm{Mg}^{2+}$.

Mössbauer spectra ${ }^{57} \mathrm{Fe}$ at $293 \mathrm{~K}$ of $\mathrm{Li}_{0.5} \mathrm{Fe}_{2,5-\mathrm{x}} \mathrm{Mg}_{\mathrm{x}} \mathrm{O}_{4}$, system, where $\mathrm{x}=0.0 ; 0.2 ; 0.4 ; 0.6$ and 0.8 , are a superposition of the magnetically ordered part, presented in the form of two sextuplets. One of which can be attributed to iron in a tetrahedral environment, and the other in an octahedral and paramagnetic doublet, the intensity of which increases with substitution. The value of the isomeric shift of all investigated systems is approximately $0.2-0.4 \mathrm{~mm} / \mathrm{s}$, which is a sign of the presence of iron in the $\mathrm{Fe}^{3+}$ state with electronic configuration $\left(3 d^{5} 4 s^{0}\right)$. The value of quadrupole splitting for all systems is very small (almost no different from zero), which indicates that the field on the nucleus is spherically symmetric. As the magnesium content increases, the fields on ${ }^{57} \mathrm{Fe}$ nuclei decrease, and in the tetrahedral field decreases faster than in octahedral.

The magnetic characteristics change nonmonotonically with substitution: they increase to the value of the degree of substitution of 0.4 , with a further increase in the magnesium content; the nature of their behavior tends to decrease. Upon substitution, magnesium ions are redistributed along the lattices of the spinel structure in a ratio of $8: 2$ ( 8 - in the A-site) and as a result, the balance of magnetic ions is in favor of the B-site. The decrease in magnetic characteristics with subsequent replacement is associated with a general decrease in the number of magnetic ions.

\section{Acknowledgements}

Authors acknowledge Faculty of Physics and Technology of Vasyl Stefanyk Precarpathian National University, Ukraine, for X-ray and Mössbauer measurements, Rzeszow University of Technology, Rzeszow, Poland, for SEM measurements.

Mazurenko Ju.S. - Candidate of Physical and Mathematical Sciences, Assistant Professor at the Department of Medical Informatics, Medical and Biological Physics.

[1] T. Munawar, M.S. Nadeem, F. Mukhtar, A. Azhar, M. Hasan, K. Mahmood, A. Hussain, A. Ali, M.I. Arshad, M. Ajaz un Nabi, \& F. Iqbal, Physica B: Condensed Matter. 602, 412555 (2021) (https://doi.org/10.1016/j.physb.2020.412555).

[2] M.I. Arshad, S. Arshad, K. Mahmood, A. Ali, N. Amin, Umaid-ur-Rehman, M. Isa, A. Akram, N.Sabir, \& M. $\begin{array}{lllll}\text { Ajaz-un-Nabi, } \quad \text { Physica } & \text { B: } \quad \text { Condensed }\end{array}$ (https://doi.org/10.1016/j.physb.2020.412496).

[3] C. Ma, \& Y. Zhang, Separation and Purification Technology 258, 118024 (2021) (https://doi.org/10.1016/j.seppur.2020.118024).

[4] V.K. Jha, A.K. Sijo, S.N.Alam, \& M. Roy, Journal of Superconductivity and Novel Magnetism 33(2), 455 (2019) (https://doi.org/10.1007/s10948-019-05206-5).

[5] O.M. Uhorchuk, V.V. Uhorchuk, M.V. Karpets, \& M.I. Hasyuk, Journal of Nano- and Electronic Physics 7(2), 1 (2015).

[6] B.K. Ostafiychuk, I.M. Gasyuk, L.S. Kaikan, V.V. Ugorchuk, \& P.O. Sulym, Electrochemical Power Engineering 11 (1), 18 (2011).

[7] A.K. Sijo, N. Lakshmi, K. Venugopalan, D.P. Dutta, \& V.K. Jain, Advanced Porous Materials 2(3), 189 (2015) (https://doi.org/10.1166/apm.2014.1071). 
[8] L.S. Kaykan, Ju.S. Mazurenko, \& V.I. Makovysyn, Applied Nanoscience 10(8), 2739 (2020) (https://doi.org/10.1007/s13204-020-01259-4).

[9] K. Ishii, S. Doi, R. Ise, T. Mandai, Y. Oaki, S. Yagi, \& H. Imai, Journal of Alloys and Compounds 816, 152556 (2020) (https://doi.org/10.1016/j.jallcom.2019.1525).

[10] S. Ikram, J. Jacob, M.I. Arshad, K. Mahmood, A. Ali, N. Sabir, N. Amin, \& S. Hussain, Ceramics International 45(3), 3563 (2019) (https://doi.org/10.1016/j.ceramint.2018.11.015).

[11] A.K. Sijo, V.K. Jha, L.S. Kaykan, \& D.P. Dutta, Journal of Magnetism and Magnetic Materials 497, 166047 (2020) (https://doi.org/10.1016/j.jmmm.2019.166047).

[12] R. Singh Yadav, I. Kuřitka, J. Havlica, M. Hnatko, C. Alexander, J. Masilko, L. Kalina, M. Hajdúchová, J. Rusnak, \& V. Enev, Journal of Magnetism and Magnetic Materials 447, 48 (2018) (https://doi.org/10.1016/j.jmmm.2017.09.033).

[13] L. Kaykan, A.K. Sijo, A. Żywczak, J. Mazurenko, \& K. Bandura, Applied Nanoscience 10(12), 4577 (2020) (https://doi.org/10.1007/s13204-020-01413-y).

[14] K. Wieczerzak, A. Żywczak, J. Kanak, \& P. Bała, Materials Characterization 132, 293 (2017) (https://doi.org/10.1016/j.matchar.2017.08.030).

[15] W. Maziarz, A. Wójcik, P. Czaja, A. Żywczak, J. Dutkiewicz, Ł. Hawełek, \& E. Cesari, Journal of Magnetism and Magnetic Materials 412, 123 (2016) (https://doi.org/10.1016/j.jmmm.2016.03.089).

\author{
Ю.С. Мазуренко
}

\title{
Вплив заміщення іонів магнію на структуру та магнітні властивості літісвого фериту
}

Івано-Франківський національний медичний університет, Івано-Франківськ, Украӥна, уитаzигепко@ifnти.еdи.иа

Порошки нанорозмірного літієвого фериту, заміщеного іонами магнію були отримані методом зольгель авто спалювання. Показано, що даний метод забезпечує високу фазову чистоту і однорідність синтезованого продукту а також володіє значною енергоекономічністю порівняно 3 традиційним твердофазним методом. Шпінельна структура заміщеного літієвого фериту була підтверджена результатами X-променевої дифракції а також визначені розміри частинок методами X-променевої дифрактометрії і мессбауерівського аналізу. Мессбауерівські спектри показали присутність двох магнітовпорядкованих підсистем, що відповідають за тетраедричнне і октаедричне оточення заліза та двох парамагнітних дублетів, один з яких відповідає за присутність заліза у двовалентному стані. Магнітні характеристики були отримані для кілець, виготовлених з синтезованого матеріалу. Вимірювання показали немонотонну залежність намагніченості насичення, залишкової намагніченості, коерцитивної сили та магнітного моменту від складу і виявили значно вищі показники, порівняно з аналогічними матеріалами, отриманими твердофазним синтезом. Характер поведінки магнітних характеристик при заміщенні іонами магнію пов'язаний з особливостями катіонного розподілу і їх мікроструктури, що в основному визначається способом отримання фериту.

Ключові слова: ферити, золь-гель автоспалювання, структурні дослідження, магнітні властивості, шпінелі, м'які магніти. 